\title{
The Dilemma Faced by Dongguan Foreign Trade Companies in the Post-epidemic Era and Transformation Development Research
}

\author{
Jiahui Liang ${ }^{1, \text { a }}$, Fei Lei ${ }^{1, *}$, Yingtong Deng ${ }^{1, b}$ \\ ${ }^{1}$ School of Finance and Economics, Guangdong University of Science and Technology, Dongguan, China
}

\begin{abstract}
The gradual increase in China's economic strength has driven the economic development of the foreign trade industry. However, due to the impact of the new coronavirus in 2020, many countries and cities have suffered economic recession, companies have closed down, and flights have been suspended. Therefore, the development of Dongguan's foreign trade enterprises has also been hit to a certain extent, and many problems have appeared. During the post-epidemic period, Dongguan foreign trade companies faced problems such as lack of human resources, difficulties in resuming work and production, obstacles in logistics and transportation, and substantial increase in costs. This article analyzes the difficulties faced by Dongguan's foreign trade enterprises, and puts forward countermeasures to seek the transformation and development of foreign trade enterprises.
\end{abstract}

\section{Introduction}

Table 1. 2015-2019 Import and Export Trade Volume of Dongguan City (Unit: 100 trillion yuan).

\begin{tabular}{|c|c|c|c|c|c|}
\hline Year & $\mathbf{2 0 1 5}$ & $\mathbf{2 0 1 6}$ & $\mathbf{2 0 1 7}$ & $\mathbf{2 0 1 8}$ & $\mathbf{2 0 1 9}$ \\
\hline Total export & 6.43 & 6.56 & 7.03 & 7.97 & 8.63 \\
\hline Total import & 3.97 & 4.85 & 5.23 & 5.46 & 5.17 \\
\hline Total import and export & 1.04 & 1.14 & 1.23 & 1.34 & 1.38 \\
\hline Growth rate (\%) & & 9.77 & 7.43 & 9.41 & 2.85 \\
\hline
\end{tabular}

Data source: Dongguan Municipal Bureau of Statistics

Table 2.2014-2018 Dongguan Export Commodity Structure (Unit: 100 trillion yuan).

\begin{tabular}{|c|c|c|c|c|c|c|c|c|c|c|}
\hline \multirow{2}{*}{$\begin{array}{c}\text { 2014 } \\
\text { year }\end{array}$} & \multicolumn{2}{c|}{$\begin{array}{c}\text { 2015 } \\
\text { year }\end{array}$} & \multicolumn{2}{c|}{$\begin{array}{c}\text { 2016 } \\
\text { year }\end{array}$} & \multicolumn{2}{c|}{$\begin{array}{c}\text { 2017 } \\
\text { year }\end{array}$} & \multicolumn{2}{c|}{$\begin{array}{c}\text { 2018 } \\
\text { year }\end{array}$} \\
\cline { 2 - 11 } & $\mathrm{C}$ & $\mathrm{D}$ & $\mathrm{C}$ & $\mathrm{D}$ & $\mathrm{C}$ & $\mathrm{D}$ & $\mathrm{C}$ & $\mathrm{D}$ & $\mathrm{C}$ & $\mathrm{D}$ \\
\hline \multirow{2}{*}{$\mathrm{A}$} & 4.53 & 5.8 & 4.56 & 1.6 & 4.66 & 6.3 & 5.24 & 12.2 & 6.01 & 15.2 \\
\hline & & & & & & & & & & \\
$\mathrm{B}$ & 2.37 & 8.7 & 2.30 & -3.0 & 2.58 & 17.7 & 2.89 & 11.5 & 3.44 & 19.1 \\
\hline
\end{tabular}

Note: $\mathrm{A}$ is the export of mechanical and electrical products, B is the export of high-tech products, $\mathrm{C}$ is the total export volume, and D is the range (\%). Data source: Dongguan Municipal Bureau of Statistics

The economies of the countries along the "Belt and Road" continue to grow, and the market structure of Dongguan's foreign trade is also continuously optimized. According to enterprise data, as of March this year, the number of China's import and export enterprises reached 6.41 million, and the number of jobs created exceeded 20 million. Therefore, it can be seen that foreign trade plays a very important role in promoting employment, expanding residents' income and fiscal revenue The role of this is an important driving force for China's national economic growth. At the end of 2019, the beginning of 2020 should have been a good start, but a sudden new type of coronavirus has seriously affected China's economic conditions, which will greatly affect Dongguan's foreign trade companies in 2020. In order to

\footnotetext{
${ }^{*}$ Corresponding author: 2745776452@qq.com
} 
analyze the relevant data, we make the following assumptions:

Assuming the total export volume is TE, the total export volume from 2015 to 2019 is TE1, TE2, TE3, TE4, and TE5.

Assuming the total import volume is $\mathrm{T} 1$, the total export volume from 2015 to 2019 is TI1, TI2, TI3, TI4, and TI5.

Assuming import and export The total amount is TEI, and the total exports from 2015 to 2019 are TEI1, TEI2, TEI3, TEI4, and TEI5.

Assuming the growth rate is GR, from 2015 to 2019 are GR1, GR2, GR3, GR4, GR5.

For this, we build a model as:

$$
\begin{aligned}
& T E I=T E+T I \\
& G R=[T E(n+1)-T E+T I(n+1)-T I)] /(T E+T I) \\
& G R 1=[T E 2-T E 1+T I 2-T I 1)] /(T E 1+T I 1) \\
& G R 2=[T E 3-T E 2+T I 3-T I 2)] /(T E 2+T I 3)
\end{aligned}
$$$$
\text { GR5 }=[T E 6-T E 5+T I 6-T I 5)] /(T E 5+T I 5)
$$

According to statistics from the Dongguan Municipal Bureau of Statistics, from 2015 to 2019, the total import and export volume of Dongguan has been increasing year by year. Among them, the total import and export volume in 2019 was 1.380 .17 billion yuan, an increase of $2.85 \%$ over the previous year, the total export volume was 862.88 billion yuan, and the total import volume was 517.29 billion yuan, ranking fourth in the country.

$\mathrm{Mu}$ Yong doubted that Dongguan's foreign trade development has made great achievements. See Table 1 . From the perspective of the export commodity structure, the export commodity structure of Dongguan continued to improve from 2014 to 2018 . From the data in the figure, we know that the export of mechanical and electrical products and high-tech products have continued to grow in the past five years, and the proportion of exports has maintained a rapid development. Momentum, see Table 2 for details.

\section{The development status of Dongguan's foreign trade enterprises under the epidemic}

\subsection{The total import and export volume of Dongguan City has decreased compared with the same period last year}



Fig. 1. Dongguan City's total imports and exports from January to June.

Data source: Dongguan Municipal Bureau of Statistics

Affected by the epidemic, China's total import and export volume has fallen sharply. According to data released by the General Administration of Customs of China, the total value of China's imports and exports of goods from January to June 2020 is 14237.91 billion yuan, of which the total export value is 7713.41 billion yuan and the total import value is 65245.0 billion yuan. Among them, Dongguan's foreign trade industry has also been greatly affected. The total value of Dongguan's imports and exports in January was zero, and the total value of imports and exports in June was 563.34 billion yuan. Since February, the total import and export volume has only slowly increased, thanks to China's rapid control of the epidemic, the shift of focus to the resumption of work and production, and the government has introduced a series of measures to help Dongguan enterprises tide over the difficulties, as shown in Figure 1.

\subsection{The import and export volume of various enterprises in Dongguan City fell}

Table 3. The import and export situation of various enterprises in Dongguan from January to August 2020 (unit: 1 billion yuan).

\begin{tabular}{|c|c|c|c|c|}
\hline \multirow{2}{*}{} & \multicolumn{2}{|c|}{ Exit } & \multicolumn{2}{c|}{ Import } \\
\cline { 2 - 5 } & Renminbi & $\begin{array}{c}\text { RMB year- } \\
\text { on-year }\end{array}$ & Renminbi & $\begin{array}{c}\text { RMB year- } \\
\text { on-year }\end{array}$ \\
\hline Private Enterprise & 28.51 & $4.74 \%$ & 16.94 & $-7.16 \%$ \\
\hline
\end{tabular}




\begin{tabular}{|c|c|c|c|c|}
\hline $\begin{array}{c}\text { Foreign investment } \\
\text { enterprise }\end{array}$ & 23.11 & $-9.94 \%$ & 14.18 & $-4.29 \%$ \\
\hline $\begin{array}{c}\text { State-owned } \\
\text { enterprise }\end{array}$ & 0.06 & $-91.85 \%$ & 0.06 & $-73.67 \%$ \\
\hline
\end{tabular}

Data source: Dongguan Municipal Bureau of Statistics

From January to August 2020, Dongguan City's imports and exports by the nature of import and export enterprises totaled 29,940,261,200 yuan, a year-on-year decrease of $4.73 \%$ in RMB. Among them, the growth of Dongguan's foreign trade economy is inseparable from the contribution of private enterprises. From the data point of view, private enterprises have a leading advantage, with import and export growth and a higher proportion. The export of private enterprises was 285.0416663 million yuan, an increase of $4.74 \%$ yearon-year; the import of 169447.6625 million yuan, a yearon-year decrease of $7.16 \%$, is shown in Table 3. From January to August, the total import and export volume of China's private enterprises was 9.21 trillion yuan, up $8.5 \%$ year-on-year, accounting for $45.9 \%$ of China's total foreign trade value. Table 4 shows the details.

Table 4. The import and export situation of various enterprises in China from January to August in 2020 (unit: trillion yuan).

Data source: China Net Window

\begin{tabular}{|c|c|c|c|}
\hline & $\begin{array}{c}\text { Total import } \\
\text { and export }\end{array}$ & Amplitude & $\begin{array}{c}\text { Accounted for the total } \\
\text { value of China's foreign } \\
\text { trade }\end{array}$ \\
\hline Private Enterprise & 9.21 & $8.5 \%$ & $45.9 \%$ \\
\hline $\begin{array}{c}\text { Foreign investment } \\
\text { enterprise }\end{array}$ & 7.74 & $-4.3 \%$ & $38.6 \%$ \\
\hline $\begin{array}{c}\text { State-owned } \\
\text { enterprise }\end{array}$ & 3.02 & $-13.2 \%$ & $15.1 \%$ \\
\hline
\end{tabular}

\subsection{Changes in the way of import and export trade in Dongguan City}

Table 5. China's total import and export trade volume from January to August in 2020 (unit: ten thousand yuan).

\begin{tabular}{|c|c|c|c|c|c|c|}
\hline $\begin{array}{c}\text { Trade } \\
\text { Method }\end{array}$ & $\begin{array}{c}\text { Total } \\
\text { Import and } \\
\text { export }\end{array}$ & $\begin{array}{c}\text { Range } \\
\mathbf{( \% )}\end{array}$ & $\begin{array}{c}\text { Total } \\
\text { Import and } \\
\text { export }\end{array}$ & $\begin{array}{c}\text { Range } \\
(\%)\end{array}$ & $\begin{array}{c}\text { Total Import } \\
\text { and export }\end{array}$ & $\begin{array}{c}\text { Range } \\
(\%)\end{array}$ \\
\hline $\begin{array}{c}\text { Processing } \\
\text { trade }\end{array}$ & 4.68 & -6.7 & 2.97 & -6.6 & 1.71 & -6.8 \\
\hline General trade & 12.09 & 0.5 & 6.59 & 2.5 & 5.5 & -1.7 \\
\hline
\end{tabular}

Data source: China Net Window

Table 6. The total value of Dongguan's import and export trade methods from January to August 2020 (unit:1 billion yuan).

\begin{tabular}{|c|c|c|c|c|c|c|}
\hline \multirow{2}{*}{$\begin{array}{l}\text { Trade } \\
\text { method }\end{array}$} & \multicolumn{2}{|c|}{ Exit and import } & \multicolumn{2}{|c|}{ Exit } & \multicolumn{2}{|c|}{ Import } \\
\hline & Renminbi & $\begin{array}{l}\text { RMB year-on- } \\
\text { year }\end{array}$ & Renminbi & $\begin{array}{c}\text { RMB year-on- } \\
\text { year }\end{array}$ & Renminbi & $\begin{array}{l}\text { RMB year-on- } \\
\text { year }\end{array}$ \\
\hline $\begin{array}{l}\text { General } \\
\text { trade }\end{array}$ & 37.40 & $-3.57 \%$ & 29.32 & $1.3 \%$ & 80.83 & $\begin{array}{c}-18.05 \\
\%\end{array}$ \\
\hline $\begin{array}{l}\text { Processing } \\
\text { trade }\end{array}$ & 28.96 & $\begin{array}{c}-14.49 \\
\%\end{array}$ & 19.13 & $\begin{array}{c}-15.09 \\
\%\end{array}$ & 98.32 & $\begin{array}{c}-13.28 \\
\%\end{array}$ \\
\hline
\end{tabular}

Data source: Dongguan Municipal Bureau of Statistics

From January to August 2020, China's general trade import and export totaled 12.09 trillion yuan, an increase of $0.5 \%$; the total processing trade totaled 4.68 trillion yuan, a decrease of $6.7 \%$. See Table 5 for details. 
Among them, Dongguan's general trade totaled $374,223.308$ million yuan, a year-on-year decrease of $3.57 \%$ in RMB; processing trade was 289634.7176 million yuan, a year-on-year decrease of $14.49 \%$. See Table 6 for details. General trade imports and exports have increased and the proportion has increased. Although Dongguan's foreign trade structure has been further optimized, Dongguan's dependence on foreign trade is still very large, and it is necessary to reduce its dependence on foreign trade. In recent years, through the implementation of innovative development of processing trade, Dongguan has led to systematic support for innovation, encouragement and guidance of processing enterprises to create, acquire and introduce brands, and expand overseas marketing networks with their own brands.

\subsection{Orders for export commodities in Dongguan are affected}

Affected by the epidemic, orders for labor-intensive industries have been severely lost. From January to April, Dongguan's exports of labor-intensive products were 18.23 billion yuan, down $27.5 \%$, and exports of clothing and clothing accessories fell by $40.6 \%$. The latest survey by Dongguan Customs shows that the number of workers in a large garment manufacturing company in Dongguan has reached more than $93 \%$, and $70 \%$ are export orders, but almost all of them have been cancelled, and production capacity has dropped by about $30 \%$.

\section{Difficulties facing Dongguan's foreign trade enterprises in the development of post-epidemic}

\subsection{Lack of human resources and difficulty in resuming work and production The epidemic happened to spread to various places during the Spring Festival}

People realized the seriousness of the epidemic and did not dare to go out. Due to the rapid spread of the epidemic, various provinces in China have also formulated measures to manage the movement of people, and even some places have begun to close the cities one after another, and the entry and exit of people is strictly prohibited, which has seriously affected the mobility of people. This has made it more difficult for companies to resume work and production. Although some companies have started construction, the lack of anti-epidemic materials such as masks has made it difficult for companies to resume work.

\subsection{Decline in demand for foreign trade products}

Affected by the epidemic, foreign countries have gradually begun to lock down cities, restricting people's travel, and severely affecting people's consumption. Except for medical supplies and daily necessities, almost all other needs have stagnated. Although the World Health Organization also emphasizes that the epidemic will not spread through international logistics, people's purchasing mentality, purchasing psychology, and purchasing behavior will still be affected and fluctuated to a certain extent.

\subsection{There are obstacles to logistics and transportation, and the cost is greatly increased}

Foreign trade transportation mainly relies on sea transportation. Due to the impact of the epidemic, many ports, terminals and airlines have stopped importing and exporting goods. According to the relevant regulations of the epidemic, each import and export of goods must be quarantined and disinfected multiple times, which has led to the entire The decline in international express delivery capacity affects the timeliness of logistics. At the beginning of the outbreak in China, the United States and Singapore began to stop flights to China, and the number of international flights decreased, which led to the delivery of goods in the entire logistics industry.

\subsubsection{Foreign trade orders are cancelled and the return rate is high}

Since late February, the new coronavirus has spread in Japan, South Korea, Iran and other countries. Under the outbreak of the epidemic, Chinese foreign trade companies are facing risks in all aspects of international trade. If they cannot purchase on time, foreign trade companies will inevitably face high breach claims. Affected by the epidemic, the Spring Festival holiday was extended. Most of the orders signed by foreign trade companies a year ago were due to insufficient downstream operations, and upstream raw material companies did not resume work, resulting in orders not being delivered in time. Export companies are mainly affected by overseas market conditions, and there are no orders, business negotiations, etc. A rebound in export orders will boost export confidence (Investigation by the Ministry of Commerce, 2013) [1].

\subsubsection{The industry chain is under impact}

Due to the global spread of the epidemic, the epidemic situation in different countries is at different stages, and there is no basis for coordinated resumption of work. This has increased the difficulty of coordination of the global industrial chain and supply chain, so that the global supply chain has been greatly affected. On the one hand, due to the impact of supply interruption risks, personnel restrictions, logistics stagnation and insufficient production capacity; on the other hand, the impact of reduced orders, customer transfer, reduced turnover and blocked freight on the demand side. China has integrated into the global industrial chain. Whether it is a high-tech provider or a low-tech provider, all links in the chain are closely connected, and the industrial chain has an important position. From the perspective of global value chains, the impact of the epidemic on foreign trade 
companies is mainly service-oriented small and mediumsized foreign trade companies and foreign trade companies in key epidemic areas. However, the impact on foreign trade companies will inevitably be transmitted to the corresponding foreign trade companiesas shown in picture 2 .

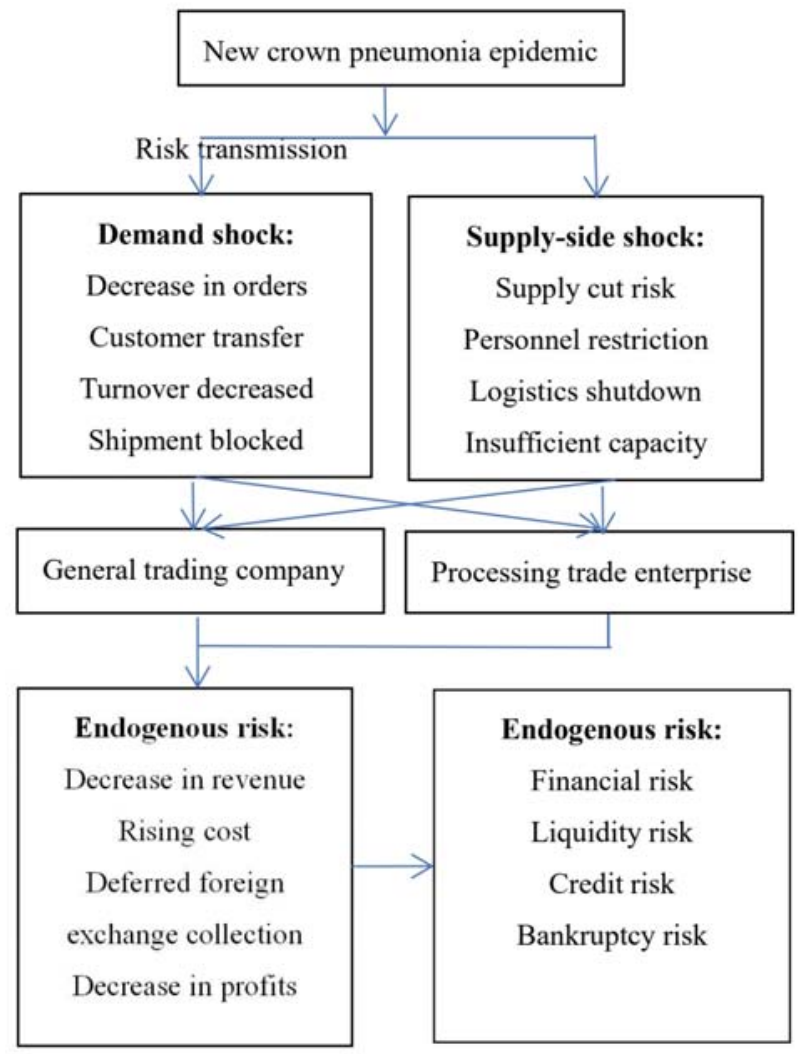

Fig. 2. The risk transmission mechanism of the impact of the epidemic on foreign trade companies

\section{Research on countermeasures for the transformation and development of foreign trade enterprises in Dongguan under the post-epidemic situation}

At present, as the epidemic situation in China is slowly brought under control, the foreign trade industry in Dongguan has gradually resumed work and production. In response to the challenges posed by the new crown pneumonia epidemic, the State Council has issued a series of "stabilizing foreign trade and foreign investment" policies (hereinafter referred to as "double stability" policies) to alleviate the impact of the epidemic on foreign trade, maintain and win orders, and stabilize foreign trade basics. [2] Companies can seize the opportunity to promote industrial transformation and upgrading, and better promote the economic development of Dongguan's foreign trade industry.

\subsection{Converting production of anti-epidemic products to become the core product of the enterprise}

Currently, anti-epidemic items such as masks, thermometers and alcohol have become necessities of our lives. According to the Dongguan News Network, Dongguan Jinsheng Shoe Material Factory originally produced shoe materials. Realizing the severity of the epidemic and the shortage of epidemic prevention materials, it switched to producing epidemic prevention materials to meet people's needs. This method can not only enable enterprises to change their production methods and main business scope, but also meet the current needs of the country and the people. Good use of epidemic prevention materials can play a good role in epidemic prevention, protecting both themselves and others.

\subsection{Implement diversified foreign trade methods}

Affected by the global epidemic, the world economy has suffered a severe recession. The transformation from foreign trade to domestic sales takes full advantage of the online platform. Broaden the channel for foreign trade to domestic sales, carry out online thematic docking activities of well-known e-commerce platforms such as Tmall 1688 Koala, and actively build a foreign trade cloud exhibition platform, guide enterprises to more vigorously connect with foreign trade platforms such as Amazon, build digital exhibition halls, and strengthen Cooperate with large-scale domestic and foreign exhibition companies, cooperate with offline physical exhibitions, increase financial subsidies for enterprises to participate in digital exhibition halls, and realize online participation of foreign trade companies to expand overseas markets. [3]

\subsection{Promote the coordinated development of enterprise industrial chain and supply chain}

With the development of trade globalization, countries in the world have gradually formed an industrial chain with highly globalized characteristics, and China's economy has been deeply integrated into the global industrial chain (Hu Guoliang and Wang Jiyuan, 2020). [4] Continuous "blood transfusion support" to ensure the stability of the supply chain of the industry chain. Stabilize the operation of the industrial chain supply chain, promote the coordinated development of industrial chain enterprises and supply chain enterprises, increase the key imported raw materials required for enterprise production, and ensure the stable and safe development of the supply chain. Persist in innovative development, promote the development of the foreign trade industry chain with high technology, and accelerate the transformation and upgrading. Leveraging the advantages of Dongguan's manufacturing industry, encouraging the use of high technology, and vigorously promoting the transformation and upgrading of the foreign trade industry is conducive to adjusting and 
optimizing the structure of foreign trade commodities and industries.

\subsection{Maintain good relations with trading countries}

In recent years, Dongguan has maintained good cooperative relations with trading countries. For example, the watches produced by Deli Watches disappeared from EU countries such as Indonesia. In view of the objective existence of the global development of the novel coronavirus epidemic on foreign cooperative companies, a certain degree of contract breach is bound to occur. Chinese companies should not rely excessively on contract breach performance measures to resolve their dilemmas while safeguarding legitimate and reasonable rights and interests. Communicate and cooperate with foreign companies to fight against the impact of the new crown pneumonia, which will reduce transaction risks[5], and maintain good relations with trading countries through the following measures.

To consolidate the relationship with old customers, you can give away some masks, alcohol and other antiepidemic materials to customers for free, so that customers feel cared and maintain a long-term cooperative relationship. Adjust and open up foreign markets, including ASEAN, Central Asia, Russia and other low-risk regions of the epidemic. Actively negotiate with customers and use the force majeure clause in the contract to negotiate with overseas customers about delays in delivery or cancellation of orders.

\section{Conclusion}

The epidemic is actually a "double-edged sword", bringing many challenges and opportunities. Although the epidemic has a great impact on foreign trade companies this time, we must have the confidence to overcome it. Dongguan should seize this opportunity to promote the development of Dongguan's foreign trade enterprises. At the same time, it should also seize the development opportunity to accelerate the "out of the country" of Dongguan products.

\section{Acknowledgements}

This paper is sponsored by this fund, Fund Project: Guangdong University of Science and Technology's 2019 school-level scientific research project "Research on the Construction Path of Guangdong-Hong KongMacao Greater Bay Area International Technology Innovation Center"; Guangdong University of Science and Technology's 2020 school-level "quality engineering" project teaching achievement cultivation project "'School-run-enterprise" collaboration Research on the Construction of Innovation and Entrepreneurship System for Cultivating Cross-border E-commerce Talents."

\section{References}

1. Investigation by the Ministry of Commerce. Thousands of foreign companies' export orders have rebounded. Export confidence has been restored, China Foreign Trade, (5): 20-21(2013)

2. Lawrence Boone. How to deal with the impact of the new crown pneumonia epidemic on the global economy, China Economic Report, (2): 138144(2020)

3. Y.Peng, An Empirical Study on the International Competitiveness of China's Textile and Apparel Industry, World Economic Research, (11): 6468(2009)

4. M.Xi, Analysis on the Competitiveness and Complementarity of Sino-Korea Bilateral Trade , Journal of Inner Mongolia Agricultural University (Social Science Edition), (06): 58-63 (2016 )

5. H.Du, Analysis of retaliation and adjudication in the settlement of international trade disputes-Taking WTO and free trade agreements as examples, International Trade Exploration,(01): 103-116(2019) 